\title{
Pengaruh Budaya Organisasi terhadap Kinerja Pegawai pada Dinas Pendidikan Provinsi Sulawesi Selatan
}

\author{
Jamaluddin, Rudi Salam, Harisman Yunus \& Haedar Akib \\ Universitas Negeri Makassar
}

\begin{abstract}
ABSTRAK
Penelitian ini bertujuan untuk mengetahui, Pengaruh Budaya Organisasi Terhadap Kinerja Pegawai Pada Kantor Dinas Pendidikan Pemerintah Provinsi Sulawesi Selatan. Penelitian ini merupakan penelitian kuantitatif yang menunjukkan hubungan yang bersifat sebab-akibat. Sampel dalam penelitian ini sebanyak 47 pegawai. Teknik pengumpulan data yang digunakan adalah observasi, angket dan dokumentasi. Teknik analisis data yang digunakan yaitu analisis statistik deskriptif dengan menggunakan persentase, rata-rata, dan standar deviasi serta untuk analisis statistik inferensial menggunakan uji normalitas data, analisis regresi linear sederhana, dan analisis korelasi product moment. Hasil penelitian menunjukkan budaya organisasi berada pada kategori sangat baik ditinjau dari segi indikator yaitu : Inovasi dan Keberanian mengambil risiko; Perhatian terhadap detail; Berorientasi kepada hasil; Berorientasi kepada manusia; Berorientasi tim; Agresif; dan Stabil. Kinerja Pegawai berada pada kategori sangat baik ditinjau dari indikator Kedisiplinan petugas pelayanan, Tanggung jawab petugas pelayanan, Kemampuan petugas pelayanan, Kesopanan dan keramahan petugas, berdasarkan analisis regresi linear sederhana menunjukkan bahwa terdapat Pengaruh Budaya Organisasi Terhadap Kinerja Pegawai Pada Kantor Dinas Pendidikan Pemerintah Provinsi Sulawesi Selatan. Dari hasil analisa korelasi product moment diperoleh tingkat hubungan yang signifikan antara pengaruh budaya organisasi terhadap kinerja pegawai pada kantor Dinas Pendidikan Pemerintah Provinsi Sulawesi Selatan dengan kategori Kuat.
\end{abstract}

Kata kunci: Budaya organisasi dan Kinerja pegawai

\begin{abstract}
This study aims to investigate, The Influence of Organizational Culture on Employee Performance At the Office of Education Institution Office of South Sulawesi Provincial Government. This study is a quantitative research that shows a causal relationship. The sample in this research is 47 employees. Data collection techniques used were observation, questionnaires and documentation. Data analysis techniques used were descriptive statistical analysis using percentage, average, deviation standard and for inferential statistical analysis using data normality test, simple linear regression analysis, and 'product moment' correlation analysis. The results showed that organizational culture is in excellent category in terms of indicators of Innovation and Courage to take risks; Attention to detail; Resultsoriented; Human-oriented; Team-oriented; Aggressive; And Stable. Employee Performance is in excellent category in Indicator of service officer, Responsibility of service officer, Ability of service officer, Courtesy and hospitality officer. Based on the simple linear regression analysis, it indicates that there is Influence of Organizational Culture on Performance Of Employee At Education Institution Office Of South Sulawesi Provincial Government. According to the result of product moment correlation analysis, it is noted that there is a significant level of relationship between the influence of organizational culture on the performance of employees at the Education Institution Office of South Sulawesi Provincial Government with the strong category.
\end{abstract}

Keywords: The Organizational Culture, Employee Performance 


\section{PENDAHULUAN}

Manusia sebagai makhluk sosial pada dasarnya mempunyai sifat untuk bersosialisasi, bekerja sama dan membutuhkan keberadaan manusia lainnya (Abdullah, 2003; Anak, 1995; Marcella, 2004; Soegandhi \& Sutanto, 2013; Suryana, 2011). Oleh karena itu, keberadaan sebuah organisasi sangat diperlukan sebagai suatu wadah yang dapat menghimpun atau mempermudah manusia dalam bersosialisasi dan bekerja sama. Untuk itu Sumber daya manusia merupakan bagian yang memiliki peranan penting dalam suatu organisasi yang menjadi perencana dalam setiap aktivitas-aktivitas organisasi. Beberapa kegiatan pengelolaan sumber daya manusia misalnya pengadaan, pelatihan, motivasi pegawai, penilaian, peningkatan kedisiplinan dan lain-lain. Sumber daya manusia merupakan asset yang harus terus menerus diperhatikan untuk memperoleh sumber daya manusia yang memiliki kinerja yang baik, sehingga dapat mengembangkan organisasi dalam berbagai tuntutan masyarakat dan perkembang zaman. Dalam upaya mendukung pencapaian tujuan organisasi, diperlukan pula sumber daya manusia yang berkualitas dan professional. Sumber daya manusia yang professional dan berkualitas cenderung memiliki kinerja yang lebih baik, sehingga upaya peningkatan kualitas sumber daya manusia sangat penting untuk diperhatikan oleh pimpinan organisasi (Akib, 2008; Dharma \& Akib, 2009; Ismail, Sulur, Akib, \& Salam, 2016; Saggaf, Salam, Kahar, \& Akib, 2014).

Dalam organisasi pemerintahan/publik di Indonesia, kinerja organisasi pemerintahan merupakan hal yang sangat penting guna mewujudkan tata kelola pemerintahan yang baik (good governance) dan pemerintahan yang bersih (clean governance), serta mendukung tugas-tugas pemerintahan untuk memberikan pelayanan yang terbaik kepada masyarakat sesuai dengan ciri khasnya sebagai organisasi pemerintahan yaitu berorientasi pada pelayanan publik (service public oriented), bukan untuk mecari laba (profit oriented) (Azizy, 2007). Berdasarkan pandangan masyarakat secara umum, salah satu tantangan besar organisasi pemerintahan saat ini adalah melaksanakan kinerja secara efektif dan efesien karena selama ini instansi pemerintahan diidentikkan dengan kinerja yang lambat, rumit, berbelit-belit dan penuh dengan Korupsi, Kolusi dan Nepotisme (Azizy, 2007; Moeljono, 2003; Nurbarani, 2009; Saputra, 2014).

Dalam rangka meningkatkan kinerja pegawai yang berkualitas dan professional salah satu faktor yang cocok untuk diterapkan dalam lingkungan kerja ialah budaya organisasi. Budaya organisasi dapat membantu kinerja pegawai, karena menciptakan suatu tingkat motivasi yang luar biasa bagi pegawai untuk memberikan kemampuan terbaiknya dalam memanfaatkan kesempatan yang diberikan oleh organisasinya. Untuk menerapkan budaya organisasi yang cocok pada sebuah organisasi, maka diperlukan adanya dukungan dan partisipasi dari semua anggota yang ada dalam lingkup organisasi tersebut.

Kantor Dinas Pendidikan Pemerintah Provinsi Sulawesi Selatan juga tidak ingin ketinggalan dalam membangun budaya organisasi yang efektif guna menciptakan hasil kerja, disiplin kerja dan kualitas kerja pegawai yang lebih baik. Pemerintahan dituntut untuk memiliki visi dan misi yang jelas, strategik dan setiap kompenen didalamnya juga dituntut untuk dapat merealisasikan visi dan misi pemerintahan. Visi dan misi inilah yang kemudian melahirkan nilai-nilai yang diyakini oleh anggota dan mencerminkan budaya organisasi. 
Jamaluddin, Rudi Salam, Harisman Yunus E Haedar Akib, Pengaruh Budaya Organisasi terhadap Kinerja Pegawai pada Dinas Pendidikan Provinsi Sulawesi Selatan |27

Dinas pendidikan sebagai institusi yang berwenang dalam mengelola dan melaksanakan pendidikan bagi anak bangsa, berperan sebagai transformer budaya terhadap pengembangan amanat dan pemegang estafet pemerintahan dimasa yang akan datang. Di lembaga inilah aktifitas para pegawai diharapkan mampu berperan dalam mewujudkan suatu pola pendidikan serta mampu mengatasi segala permasalahan yang berhubungan dengan kualitas pendidikan. Kantor Dinas Pendidikan Pemerintah Provinsi Sulawesi Selatan yang bertanggung jawab dalam mengembangkan, meningkatkan kualitas dan mengkordinasikan unsur pendidikan di lingkup Provinsi Sulawesi Selatan.

Berdasarkan hasil observasi yang telah dilakukan oleh peneliti pada tanggal 27 s/d 31 Maret 2017. Ditemukan beberapa masalah berdasarkan hasil pengamatan yang dilakukan oleh peneliti yaitu (1) beberapa pegawai masih kurang bertanggung jawab terhadap tugas dan tanggung jawab yang di amanahkan kepadanya. Seperti terlihat masih banyaknya pegawai suka melalaikan pekerjaannya. (2) beberapa pegawai masih terlihat terlambat datang kerja dan meninggalkan kantor pada saat jam kerja. Hal ini terlihat masih ada pegawai yang lebih mementingkan urusan pribadi diluar dari urusan kantor. Misalnya meninggalkan kantor dengan alasan mengikuti acara keluarga yang mungkin tidak begitu penting. (3) kinerja pegawai masih belum sesuai dengan harapan lembaga. Misalnya pegawai belum mampu memenuhi target selesainya tugas yang deadline, dan perlunya waktu cukup lama ketika masyarakat yang ingin mengurus berkas yang bersangkutan dengan Kantor Dinas Pendidikan Provinsi.

\section{METODE PENELITIAN}

Penelitian ini adalah penelitian asosiatif yang dimaksudkan untuk menjelaskan pengaruh tingkat pendidikan dan pelatihan terhadap kinerja pegawai pada Kantor Dinas Pendidikan

Provinsi Sulawesi Selatan. Penelitian ini pada dasarnya akan mengkaji hipotesis dan mengadakan interprestasi tentang pengaruh variabel independent terhadap variabel dependent. Untuk mengukur variabel penelitian ini, maka digunakan angket berskala Likert yang akan diisi oleh responden sesuai dengan indikator variabel.

Adapun populasi dalam penelitian ini sebanyak 235 pegawai, sedangkan jumlah pegawai yang menjadi sampel adalah 47 orang. Peneliti mengambil $20 \%$ dari jumlah populasi 235 pegawai dengan menggunakan teknik Proportionate Random Sampling sebanyak 47 orang pegawai. Teknik pengumpulan data yang digunakan dalam penelitian ini, yaitu melalui pengamatan (observasi), angket (kuesioner), dan dokumentasi. Rancangan analisis data yang digunakan dalam penelitian ini adalah rancangan analisis statistik deskriptif dan rancangan analisis statistik inferensial.

\section{HASIL PENELITIAN PEMBAHASAN}

\section{Analisis data}

Untuk mengetahui pengaruh budaya organisasi terhadap kinerja pegawai, digunakan instrument angket sebagai teknik pengumpulan data untuk variable $\mathrm{X}$ sebagai variable Budaya 
Organisasi dan nilain angket untuk variable Y sebagai Kinerja Pegawai. Selanjutnya, dalam pengujian hipotesis, maka dilakukan uji kuantitatif menggunakan rumus-rumus statistic serta perangkat lunak komputer dengan Program Statistical Standar Solusion (SPSS) yang dianggap relevan untuk analisis data yang bertujuan untuk mengetahui bagaimana tingkat pengaruh budaya organisasi terhadap kinerja pegawai.

\section{Analisis Statistik Deskriptif}

Untuk memperoleh pengaruh Budaya Organisasi Terhadap Kinerja Pegawai Pada Kantor Dinas Pendidikan Pemerintah Provinsi Sulawesi Setan, maka kedua variable dibuatkan table frekuensi dan persentase. Variable budaya organisasi (variable X) diukur dengan menggunakan kategori sangat baik, baik, cukup baik, kurang baik, sangat tidak baik. Sedangkan variabel kinerja pegawai (variabel Y) diukur dengan kategori yang sama yaitu sangat baik, baik, cukup baik, kurang baik, sangat tidak baik.

\section{a. Deskripsi Budaya Organisasi}

Analisis deskriptif dimaksudkan untuk mengetahui gambaran budaya organisasi pada kantor Dinas Pendidikan Pemerintah Provinsi Sulawesi Selatan. Data yang disajikan dalam penelitian ini adalah data yang diperoleh sebagai hasil skor dari angket penelitian yang berkaitan dengan variabel budaya organisasi. Variabel budaya organisasi terdiri dari atas 7 (tujuh) indikator yaitu: (1) Inovasi dan Keberanian mengambil risiko; (2) Perhatian terhadap detail; (3) Berorientasi kepada hasil; (4) Berorientasi kepada manusia; (5) Berorientasi tim; (6) Agresif; dan (7) Stabil. Untuk lebih jelasnya dapat dilihat pada table 1.

\section{Tabel 1}

Rangkuman Analisis Data Per Indikator Variabel Budaya organisasi

\begin{tabular}{cccccc}
\hline No & Indikator & $\mathbf{n}$ & $\mathbf{N}$ & $\mathbf{\%}$ & Karegori \\
\hline 1. & Inovasi dan Keberanian mengambil risiko & 573 & 690 & 83,04 & Sangat Baik \\
2. & Perhatian terhadap detail & 618 & 690 & 89,57 & Sangat Baik \\
3. & Berorientasi kepada hasil & 628 & 690 & 91,01 & Sangat Baik \\
4. & Berorientasi kepada manusia & 593 & 690 & 85,94 & Sangat Baik \\
5. & Berorientasi tim & 616 & 690 & 89,28 & Sangat Baik \\
6. & Agresif & 574 & 690 & 83,19 & Sangat Baik \\
7. & stabil & 414 & 460 & 90,00 & Sangat Baik \\
\hline & Jumlah & $\mathbf{4 0 1 6}$ & $\mathbf{4 6 0 0}$ & $\mathbf{8 7 , 3 0}$ & Sangat Baik \\
\hline
\end{tabular}

Selanjutnya, ketujuh indikator budaya organisasi akan diuraikan sebagaimana berikut:

\section{1) Inovasi Dan Keberanian Mengambil Risiko}

Pegawai memiliki dorongan untuk terus berinovasi seperti berkreativitas dalam melakukan pekerjaannya serta berani mengambil risiko dan bertanggung jawab terhadap tugas yang dikerjakannya. Menguasai pemahaman inovasi dan keberanian mengambil resiko menjadi 
Jamaluddin, Rudi Salam, Harisman Yunus \& Haedar Akib, Pengaruh Budaya Organisasi terhadap Kinerja Pegawai pada Dinas Pendidikan Provinsi Sulawesi Selatan |29

indikator variabel budaya organisasi berada pada kategori sangat baik dengan tingkat persentase 83,04 persen.

\section{2) Perhatian Terhadap Detail}

Pegawai memiliki perhatian terhadap detail dalam melaksanakan pekerjaannya seperti memperhatikan posisi kecermatan, menganalisis, dan perhatian pada setiap rincian pekerjaan. Menguasai pemahaman perhatian terhadap detail menjadi indikator variabel budaya organisasi yang berada pada kategori sangat baik dengan tingkat persentase 89,57 persen.

\section{3) Berorientasi Pada Hasil}

Pegawai mampu mencapai target atau hasil yang telah ditentukan serta mampu memanajemen pekerjaannya, yang mana hasil pekerjaan tersebut berfokus pada hasil yang ingin dicapai. Menguasai pemahaman berorientasi pada hasil menjadi indikator variabel budaya organisasi berada pada kategori sangat baik dengan tingkat persentase 91,01 persen.

\section{4) Berorientasi Kepada Manusia}

Pegawai memberikan pelayanan yang baik kepada orang yang dilayani, hal tersebut akan sangat berdampak baik kepada orang yang dilayani dan untuk pegawai dalam meningkatkan kinerjanya. Menguasi pemahaman berorientasi pada hasil menjadi indikator variabel budaya organisasi berada pada kategori sangat baik dengan tingkat persentase 85,94 persen.

\section{5) Berorientasi Tim}

Pegawai pada kantor Disdik Sul-Sel mimiliki hubungan yang baik sesama anggota sehingga mampu bekerja sama dengan baik sesama anggota-anggota lainnya dalam menyelesaikan pekerjaan. Menguasai pemahaman berorientasi tim menjadi indikator variabel budaya organisasi berada pada kategori sangat baik dengan tingkat persentase 89,28 persen.

\section{6) Agresif}

Pegawai pada kantor Disdik Sul-Sel memiliki inisiatif sendiri apa yang seharusnya dikerjakan tanpa harus menunggu perintah pimpinan agar dapat mengefesiensikan waktu pekerjaan. Menguasai pemahaman mengenai agresif menjadi indikator variabel budaya organisasi berada pada kategori sangat baik dengn tingkat persentase 83,19 persen.

\section{7) Stabil}

Pegawai pada kantor Disdik Sul-Sel memiliki dorongan untuk terus berprestasi dengan memberikan hasil kerja yang memuaskan untuk meningkatkan kinerja bukan menjadikan kinerja menurun dan tidak memiliki motivasi untuk berprestasi. Menguasai pemahaman mengenai stabil menjadi indikator variabel budaya organisasi dengan kategori sangat baik berada pada tingkat persentase 90,00 persen. 
Berdasrkan hasil analisis data seperti table 4, variabel budaya organisasi (X) berada pada kategori sangat baik dengan tingkat persentase sebesar 87,30 persen. Adapun hasil analisis ratarata dan standar deviasi variabel budaya organisasi (X) dapat dilihat pada tabel 2.

Tabel 2.

Rangkuman hasil analisis rata-rata dan standar deviasi

variabel budaya organisasi $(\mathbf{X})$

\begin{tabular}{|l|r|}
\hline N Valid & Budaya Organisasi \\
\hline \multicolumn{1}{|c|}{ Missing } & 47 \\
Mean & 0 \\
Median & 85.45 \\
Std. Deviation & 85.00 \\
Minimum & 5.449 \\
Maximum & 74 \\
\hline
\end{tabular}

Sumber: Hasil analisis statistic melalui program SPSS

Berdasarkan hasil analisis rata-rata dan standar deviasi variabel budaya organisasi pada table 5 tersebut, menunjukkan bahwa nilai rata-rata (mean) skor jawaban responden sebesar 87.30 dikonsultasikan dengan standar deviasi seperti dikemukakan pada bab III halaman 35, maka rata-rata 87,30 berada pada kategori sangat baik dengan standar deviasi 5,449. perolehan data tersebut ditinjau dari indikator Inovasi dan Keberanian mengambil risiko, Perhatian terhadap detail, Berorientasi kepada hasil, Berorientasi kepada manusia, Berorientasi tim, Agresif, dan Stabil.

\section{b. Deskripsi Kinerja Pegawai}

Analisis deskriptif dimaksudkan untuk mengetahui tingkat kinerja pegawai pada kantor dinas pendidikan pemerintah provinsi Sulawesi selatan. data yang disajikan dalam penelitian ini adalah data yang diperoleh dari hasil angket penelitian dengan variabel kinerja pegawai (Y). Pada variabel kinerja pegawai (y) yang menjadi indikator terdiri dari 4 (empat) yaitu: (1) Kedisiplinan petugas pelayanan, (2) Tanggung jawab petugas pelayanan, (3) Kemampuan petugas pelayanan, (4) Kesopanan dan keramahan petugas.

\section{Tabel 3}

Rangkuman Analisis Data Per Indikator Variabel Kinerja Pegawai

\begin{tabular}{clcccc}
\hline No & \multicolumn{1}{c}{ Indikator } & $\mathbf{n}$ & $\mathbf{N}$ & $\mathbf{\%}$ & Kategori \\
\hline 1. & Kedisiplinan petugas pelayanan & 964 & 1150 & 83,83 & Sangat baik \\
2. & Tanggung jawab petugas pelayanan & 984 & 1150 & 85,57 & Sangat baik \\
3. & Kemampuan petugas pelayanan & 924 & 1150 & 80,35 & baik \\
4. & Kesopanan dan keramahan petugas. & 1026 & 1150 & 89,22 & Sangat baik \\
\hline & Jumlah & $\mathbf{3 8 9 9}$ & $\mathbf{4 6 0 0}$ & $\mathbf{8 4 , 7 6}$ & Sangat baik \\
\hline
\end{tabular}

Sumber: hasil olah data 2017 
Jamaluddin, Rudi Salam, Harisman Yunus \& Haedar Akib, Pengaruh Budaya Organisasi terhadap

Kinerja Pegawai pada Dinas Pendidikan Provinsi Sulawesi Selatan |31

Selanjutnya, keempat indikator variabel kinerja pegawai akan diuraikan sebagai berikut.

\section{a) Kedisiplinan Petugas Pelayanan}

Pegawai pada kantor DISDIK Sul-Sel mampu konsisten dalam bekerja terutama dalam hal kedisiplinan waktu kerja. Datang, istirahat, sampai waktu pulang harus sesuai dengan waktu kerja yang telah dijadwalkan sehingga mendapatkan hasil kerja yang baik. Pegawai dengan menerapkan kedisiplinan petugas pelayanan menjadi indikator variabel kinerja pegawai dengan kategori sangat baik berada pada tingkat persentase 83,83 persen.

\section{b) Tanggung Jawab Petugas Pelayanan}

Pegawai pada kantor DISDIK Sul-Sel mampu memiliki kepekaan dengan penuh rasa tanggung jawab. Pegawai yang mampu bertanggung jawab atas tugas pokok dan fungsinya merupakan pegawai yang memiliki prestasi kerja yang baik. Kerja yang baik akan sangat dibutuhkan dalam organisasi. faktor tanggung jawab menjadi indikator dengan berada pada kategori sangat baik dengan tingkat persentase 85,57 persen.

\section{c) Kemampuan Petugas Pelayanan}

Pegawai pada kantor DISDIK Sul-Sel memiliki sumber daya manusia yang baik dengan pengetahuan yang luas dibidang dimana ia ditempatkan serta memiliki pengetahuan dibidang-bidang yang lain. Sehingga ketika mendapatkan pekerjaan baik pekerjaan yang sering dikerjakan maupun pekerjaan baru yang belum pernah dikerjakan mampu diselesaikan dengan baik. Meskipun dalam bekerja pegawai terkadang mendapatkan malasah, hal tersebut dapat diatasi dengan baik. Adanya faktor kemampuan petugas pelayanan menjadi indikator variabel kinerja pegawai berada pada kategori baik dengan tingkat persentase 80,35 persen.

\section{d) Kesopanan Dan Keramahan Petugas.}

Pegawai pada kantor DISDIK Sul-Sel mampu memberikan pelayanan secara sopan dan ramah kepada pihak yang dilayani maupun sesama rekan kerja dan kepada pimpinan. Agar pihak yang dilayani tersebut merasa senang dan nyaman ketik dilayani serta merasakan kepuasan kinerja dari organisasi tersebut. Memiliki sifat Kesopanan dan keramahan petugas menjadi indikator variabel kinerja pegawai berada pada kategori sangat baik dengan persentase 89,22 persen.

Berdasarkan analisis data yang telah diuraikan pada table 6, variabel Kinerja Pegawai (Y) berada pada kategori sangat baik dengan tingkat persentase 84,76 persen. Adapun hasil analisis rata-rata dan standar deviasi variabel kinerja pegawai (Y) dapat dilihat pada tabel 4.

\section{Tabel 4}


Rangkuman Hasil Analisis Rata-Rata Dan Standar Deviasi Variabel Kinerja Pegawai.

\begin{tabular}{|c|c|c|}
\hline & & Kinerja Pegawai \\
\hline $\mathrm{N}$ & Valid & 47 \\
\hline & Missing & 0 \\
\hline & & 82.94 \\
\hline & & 81.00 \\
\hline & & 6.735 \\
\hline & & 72 \\
\hline & & 100 \\
\hline
\end{tabular}

Sumber: Hasil analisis statistic melalui program SPSS

Berdasarkan analisis rata-rata dan standar deviasi variabel kinerja pegawai pada table 7 tersebut, menunjukkan bahwa nilai rata-rata (mean) skor jawaban responden sebesar 84,76 dikonsultasikan dengan standar deviasi seperti dikemukakan pada Bab III halaman , maka ratarata 84,76 berada pada kategori sangat baik, dengan standar deviasi 6,735 perolehan data tersebut ditinjau dari indikator Kedisiplinan petugas pelayanan, Tanggung jawab petugas pelayanan, Kemampuan petugas pelayanan, Kesopanan dan keramahan petugas.

\section{Pembahasan}

\section{Budaya organisasi}

Hasil penelitian ini menunjukkan bahwa tingkat budaya organisasi pada kantor Dinas Pendidikan Pemerintah Provinsi Sulawesi Selatan berada pada kategori Sangat Baik. Hal ini didukung oleh indikator yaitu: pendapat (Robbins, 1996), yang dimaksud dengan budaya organisasi adalah (1) Inovasi dan Keberanian mengambil risiko; (2) Perhatian terhadap detail; (3) Berorientasi kepada hasil; (4) Berorientasi kepada manusia; (5) Berorientasi tim; (6) Agresif; dan (7) Stabil. Berdasarkan dari ketujuah indikator tersebut, dapat dikatakan bahwa budaya organisasi pada kantor dinas pendidikan pemerintah provinsi Sulawesi selatan memiliki kategori sangat baik (Tabel 4). Indikator tersebut diambil dari penjelasan mengenai karakteristik dari budaya organisasi, karakteristik dari budaya organisasi tersebut sangat erat kaitannya dalam mempengaruhi kinerja pegawai.

Budaya organisasi memiliki kontribusi dalam membentuk perilaku pegawai seperti menanamkan nilai-nilai dan sikap para pegawai dalam mencapai tujuan organisasi, organisasi mampu beroperasi ketika ada nilai yang diyakini bersama. Nilai-nilai itu akan membimbing perilakunya di setiap proses aktivitasnya. Fenomena inilah yang nantinya menunjukkan bahwa faktor-faktor inilah akan membimbing para pegawai pada kantor Dinas Pendidikan Pemerintah Provinsi Sulawesi Selatan menjadi organisasi yang memiliki kinerja yang berkualitas dan professional.

\section{Kinerja Pegawai}


Jamaluddin, Rudi Salam, Harisman Yunus E Haedar Akib, Pengaruh Budaya Organisasi terhadap

Kinerja Pegawai pada Dinas Pendidikan Provinsi Sulawesi Selatan |33

Hasil penelitian ini menunjukkan bahwa kinerja pegawai pada kantor dinas pendidikan pemerintah provinsi Sulawesi seltan berada dalam kategori sangat baik. Hasil ini didukung oleh 4 (empat) indikator, yaitu (1) Kedisiplinan petugas pelayanan, (2) Tanggung jawab petugas pelayanan, (3) Kemampuan petugas pelayanan, (4) Kesopanan dan keramahan petugas. Melalui kualitas dengan memperlihatkan tingkat mutu kinerja yang baik, dengan kuantitas maka banyak pekerjaan yang terselesaiakan menggunakan waktu yang realitas singkat, begitu pula dengan penggunaan waktu yang tepat dan sangat menghargai waktu sehingga sesuai dengan pepatah barat yang memandang waktu yang terbuang sama ruginya dengan membuang uang secara cuma-cuma, dan dengan melalui kerja sama maka pekerjaan yang dilakukan lebih mudah dan cepat terselesaikan. Dari keempat aspek tersebut telah mewakili bagaimana penggambaran kinerja pegawai yang dihasilkan pegawai selama bekerja.

\section{Pengaruh Budaya Organisasi Terhadap Kinerja Pegawai}

Berdasarkan hasil analisis dapat diketahui bahwa korelasi product moment yang menunjukkan bahwa terdapat pengaruh yang signifikan budaya organisasi terhadap kinerja pegawai pada Kantor Dinas Pendidikan Pemerintah Provinsi Sulawesi Selatan, hal ini berarti hipotesis yang diajukan yaitu " Diduga ada pengaruh budaya organisasi terhadap kinerja pegawai pada kantor dinas pendidikan pemerintah provinsi Sulawesi selatan.”. dinyatakan diterima dengan tingkat pengaruh kuat. Pendapat ini menjelaskan bahwa jika budaya organisasi, termasuk di dalamnya faktor-faktor yang mengarahkan perilaku pegawai dalam meningkatkan kinerja dalam organisasi. Hal ini sesuai dengan pendapat (Dharma \& Akib, 2009) yaitu Inovasi dan Keberanian mengambil risiko; Perhatian terhadap detail; Berorientasi kepada hasil; Berorientasi kepada manusia; Berorientasi tim; Agresif; dan Stabil. Bahwa beberapa faktor budaya organisasi tersebut dapat mempengaruhi pegawai dalam meningkatkan kinerjanya. Namun dalam realita dilapangan, terdapat masih banyak hal-hal yang dapat mempengaruhi kinerja pegawai, seperti faktor sarana dan prasarana kantor, besaran gaji dan lain-lain yang tidak diselidiki dalam penelitan ini, yang dapat mempengaruhi kinerja pegawai.

\section{SIMPULAN}

Berdasarkan hasil analisis data dan pembahasan yang diuraikan pada bab sebelumnya mengenai pengaruh budaya organisasi terhadap kinerja pegawai pada kantor dinas pendidikan provinsi Sulawesi selatan, dapat dismpulkan sebagai berikut.

1. Gambaran budaya organisasi (X) pada kantor Dinas Pendidikan Provinsi Sulawesi Selatan, berada pada kategori sangat baik dalam hal ini ditinjau dari indikator seperti Inovasi dan Keberanian mengambil risiko; Perhatian terhadap detail; Berorientasi kepada hasil; Berorientasi kepada manusia; Berorientasi tim; Agresif; dan Stabil.

2. Gambaran kinerja pegawai (Y) pada kantor Dinas Pendidikan Provinsi Sulawesi Selatan, berada pada kategori sangat baik ditinjau dari indikator seperti Kedisiplinan petugas pelayanan, Tanggung jawab petugas pelayanan, Kemampuan petugas pelayanan, Kesopanan dan keramahan petugas. 
3. Data hasil uji korelasi product moment diperoleh, budaya organisasi $(\mathrm{X})$ dengan kinerja pegawai (Y) pada kantor dinas pendidikan provinsi Sulawesi selatan memiliki nilai signifikan 0,00-0,05 yang berarti terdapat korelasi yang signifikan. Dengan nilai R squere 0,399 atau besar pengaruhnya 39,9 persen. Hipotesis tersebut terbukti dengan adanya pengaruh yang signifikan budaya organisasi terhadap kinerja pegawai ditinjau dari tabel ANOVA didapatkan sebesar $\mathrm{F}_{\text {hitung }}(29,876)>\mathrm{F}_{\text {tabel }}(4,06)$, maka $\mathrm{H}_{\mathrm{o}}$ ditolak dan $\mathrm{H}_{\mathrm{a}}$ diterima yang artinya bahwa ada pengaruh yang kuat budaya organisasi terhadap kinerja pegawai pada kantor dinas pendidikan pemerintah provinsi Sulawesi selatan.

\section{DAFTAR PUSTAKA}

Abdullah, I. (2003). Penelitian Berwawasan Gender dalam Ilmu Sosial. Humaniora, 15(3), 265275.

Akib, H. (2008). Snapshot Dampak Kebijakan Publik dalam Program Pengentasan Kemiskinan. Makalah Tidak Dipublikasi. Malang.

Anak, A. K. (1995). Psikologi Perkembangan. Bandung: mandar maju.

Azizy, A. Q. A. (2007). Change management dalam reformasi birokrasi. Gramedia Pustaka Utama.

Dharma, S., \& Akib, H. (2009). Kewirausahaan Sekolah Berbasis Kreatifitas dan Inovasi. Jurnal Pendidikan Dan Kebudayaan, Edisi Khus, 102-117.

Ismail, A., Sulur, A. H., Akib, H., \& Salam, R. (2016). Snapshot of Society Social-Economic Welfare based on Human Development Index in Polewali Mandar Regency, Indonesia. In International Conference on Public Organization VI (ICONPO VI) (pp. 847-858). Thammsat University, Tha Prachan Campus.

Marcella, J. (2004). Arsitektur \& Perilaku Manusia. Grasindo.

Moeljono, D. (2003). Beyond Leadership. Elex Media Komputindo.

Nurbarani, M. (2009). Reformasi Birokrasi Pemerintah Kota Surakarta. UNIVERSITAS DIPONEGORO.

Robbins, S. P. (1996). Teori Organisasi: Struktur, Desain dan Aplikasi Terjemahan, PT. Prenhallindo, Jakarta. Broad Scope Timeliness Agregation Integration.

Saggaf, S., Salam, R., Kahar, F., \& Akib, H. (2014). Pelayanan Fungsi Administrasi Perkantoran Modern. Jurnal Ad'ministrare, 1(1), 20-27.

Saputra, B. (2014). Penguatan peran birokrasi dalam meningkatkan kualitas pelayanan publik di wilayah perbatasan Indonesia-Malaysia (Studi di wilayah Sebatik Kabupaten Nunukan Kalimantan Utara). UNPAS.

Soegandhi, V., \& Sutanto, E. M. (2013). Pengaruh kepuasan kerja dan loyalitas kerja terhadap organizational citizenship behavior pada karyawan PT. Surya Timur Sakti Jatim. Agora.

Suryana, T. (2011). Konsep dan Aktualisasi Kerukunan Antar Umat Beragama. Jurnal Pendidikan Agama Islam, 9(2), 127-136. 